\title{
Use of the Crustacean Artemia franciscana for Alternative Biotests
}

\author{
Petr Dvořák ${ }^{1}$, Katarína Beňová2 ${ }^{2}$ Michal Žd’árský1, Zbyňek Sklenár̆ ${ }^{1}$, Alena Havelková3 \\ ${ }^{1}$ Department of Biochemistry, Chemistry and Biophysics, Faculty of Veterinary Hygiene and Ecology, \\ University of Veterinary and Pharmaceutical Sciences Brno, Czech Republic \\ ${ }^{2}$ Department of Biology and Genetics, University of Veterinary Medicine Košice, Slovak Republic \\ ${ }^{3}$ Department of Physioterapy, Faculty of Medicine, Masaryk University, Brno, Czech Republic \\ Received January 13, 2010 \\ Accepted April 6, 2010
}

\begin{abstract}
Use of the crustacean Artemia franciscana for alternative biotests of the second generation was studied, and possible experimental design and applications of such tests outlined. In addition to the classical use in ecotoxicology, the test can be used in pharmacology as well, or to monitor the effects of ionizing radiation in co-exposure with some chemical compounds. The synergistic effect of co-exposure of PCB (DELOR 103), cadmium chloride and potassium dichromate with beta ${ }^{89} \mathrm{Sr}$ irradiation was shown. We also demonstrated the anti-oxidative and pro-oxidative effects of the ascorbic acid in dependence on its concentration. Use of the pharmaco-toxicological screening in search for the novel inhibitors of cyclin-dependent kinases was demonstrated as well, showing that Artemia franciscana may be used as a suitable biosensor instead of the expensive tests on higher vertebrates.
\end{abstract}

Artemia salina, synergy effects, irradiation, pharmacotoxicology

An important difference between experiments on live animals and on their tissues or cells in culture lies in the complex response of a living organism to any agent in contrast to only partial response of their tissues or cells in culture to the same agent. Experiments on tissues or cells in culture are not studies on simplified organisms but only experiments on living components of organisms as a whole (Pazourek 1992).

The environment including the aquatic ecosystems is often contaminated with various exogenous agents at low concentrations (Beňová et al. 2007; Nováková et al. 2007). Although the response of many test organisms to various agents is well-known, our knowledge of the toxicity of mixtures of such agents is rather limited. Exogenous agents at low concentrations may interact with various physical factors and/or pharmaceuticals. The effects of such co-exposure may not be revealed for some time, and there are good reasons to assume that they might be of rather chronic or subacute character (Dvořák and Beňová 2002; Beňová et al. 2006). In order to monitor the effects of such co-exposures and of mixtures of residues of various exogenous agents on the organism it is possible to extend the viability of test organisms under standard conditions (Dvořák et al. 2005).

The tests for monitoring co-exposures of low concentrations of exogenous agents should meet the following requirements: sufficient sensitivity to exogenous agents in short- or long-term tests, high homogeneity of test organisms and their low sensitivity to variable experimental conditions of tests, high reproducibility of experiments, they should represent as closed a system as possible (with minimum interactions with other environmental factors), high availability of the test organisms, and simple verification and statistical analysis of the results. But the above criteria can hardly be fulfilled by the conventional tests on vertebrates. Moreover, there are serious public demands to minimize the distress and suffering of experimental animals (Russell and Burch 1992). The European Convention for the Protection of Vertebrate Animals demands minimization of the number of experiments on laboratory animals. The Three R's concept of Reduction, Refinement

Address for correspondence:

Prof. MVDr. Petr Dvořák, CSc.

Department of Biochemistry, Chemistry and Biophysics

Faculty of Veterinary Hygiene and Ecology

University of Veterinary and Pharmaceutical Sciences Brno

Palackého 1-3, 61242 Brno, Czech Republic

Phone and fax: +420541562608

E-mail: dvorakp@vfu.cz

http://www.vfu.cz/acta-vet/actavet.htm 
and Replacement defined according to the Council of Europe has been accepted (Council of Europe 1976). These demands highly accentuate the urgency of development of the alternative biotests.

Subacute biotests of the second generation on Artemia franciscana (formerly A. salina) in various experimental designs fully match the above demands.

The aim of the study was to prove the usage of this biotest for different purposes: the co-exposure of some chemical agents combined with the exposure to ionizing radiation, the study of the anti-oxidative and pro-oxidative effects of the ascorbic acid (Vitamin C) in dependence on its concentration, and the pharmaco-toxicological screening for new cyclindependent kinase inhibitors (CDKI). For example, "Olomoucin" and "Roscovitin" used in this study belong to this very promising group of cytostatics with negligible side effects (Sklenář et al. 2006).

\section{Materials and Methods}

General procedures

The diapausing eggs of $A$. franciscana were purchased from the SANDERS Comp. (Utah, USA) under the name of "Maxima brine shrimp eggs". The hatching was performed over a period of $24 \mathrm{~h}$ in continuously aerated salt water at $25{ }^{\circ} \mathrm{C}$. The salt water contained the following chemicals of the analytical grade $\left[\mathrm{g} \cdot \mathrm{l}^{-1}\right]: 23.9 \mathrm{NaCl}$; $10.83 \mathrm{MgCl}_{2} \cdot 6 \mathrm{H}_{2} \mathrm{O} ; 2.25 \mathrm{CaCl}_{2} \cdot 6 \mathrm{H}_{2} 0 ; 0.68 \mathrm{KCl} ; 9.06 \mathrm{Na}_{2} \mathrm{SO}_{4} \cdot 10 \mathrm{H}_{2} \mathrm{O} ; 0.2 \mathrm{NaHCO}_{3} ; 0.04 \mathrm{SrCl}_{2} \cdot 6 \mathrm{H}_{2} \mathrm{O}$; $0.099 \mathrm{KBr}$, and $0.027 \mathrm{H}_{3} \mathrm{BO}_{3}$ (Dvořák 1995 ).

Each test included at least 50 specimens per each concentration of the agent tested. In a standard design 5 disposable Petri dishes ( $60 \mathrm{~mm}$ in diameter) were used. Ten specimens were plated into the dish in a total volume of $10 \mathrm{ml}$ including the tested agents. The living nauplii were counted at $24-\mathrm{h}$ intervals. The dead nauplii were not removed (the results remained unaffected by dead nauplii providing that the death rate in the control group had not exceeded $10 \%$ ).

Monitoring of co-exposures of low volume activity of ${ }^{89} \mathrm{Sr}$ and low cadmium, chromium and Delor 103 concentrations

Delor $103\left(4.5 \mathrm{ng}^{-1}\right)$ was selected to represent PCBs. PCBs produce colloidal solutions. The initial Delor 103 colloidal solution in salt water was obtained by three-day agitation. Excessive undissolved Delor 103 was then removed. One $\mathrm{ml}$ of solution containing $45 \mathrm{ng}$ Delor 103 in 1 litre of sea water was added to each dish. The concentration was determined by capillary gas column chromatography analysis, where 41 peaks were identified mainly as derivatives from di- to pentachlorides. The derivatives were identified by the Kovats index. The source of ionizing radiation was a beta emitter ${ }^{89} \mathrm{Sr}$ in a solution of $30 \mathrm{kBq} \cdot \mathrm{l}^{-1}$ volume activity. Strontium - isotope 89 was supplied by the Amersham Comp. as strontium chloride dissolved in water. The manufacturer guarantees the specific ${ }^{89} \mathrm{Sr}$ activity of $1.85-7.4 \mathrm{GBq} \cdot \mathrm{g}^{-1}$ and purity $<0.5 \%{ }^{85} \mathrm{Sr}<0.1 \%{ }^{90} \mathrm{Sr}$, with $\mathrm{pH}$ within the $5.0-9.0$ range. The resulting activity in dishes was obtained by recalculating the original activity to the reference date. The solution was then diluted with salt water to the activity ten times higher than that required in dishes.

Potassium dichromate $\mathrm{K}_{2} \mathrm{Cr}_{2} \mathrm{O}_{7}$ of analytical grade was diluted in salt water. One $\mathrm{ml}$ of the solution at a concentration 10 times higher than that in the dish was added to each dish $0.05 \mathrm{~g} \cdot \mathrm{l}^{-1}$.

In all experiments of this study, cadmium chloride dihydrate $\mathrm{CdCl}_{2} \cdot 2.5 \mathrm{H}_{2} \mathrm{O}\left(0.02 \mathrm{~g} \cdot \mathrm{l}^{-1}\right)$ of analytical grade (Lachema Brno) was used. Salt water was used in both the initial solution and subsequent dilutions. One $\mathrm{ml}$ of solution at a concentration 10 times higher than that used in a dish was added to each dish.

A standard design of the biotest was used (see General procedures).

Anti-oxidative and pro-oxidative effects of the ascorbic acid

The oxidizing agent was hydrogen peroxide at $0.4 \mathrm{~g} \cdot 1^{-1}$ concentration. The anti-oxidative substance was the ascorbic acid at 0.3 or $0.1 \mathrm{~g} \cdot 1^{-1}$ concentrations. The test had a standard layout described in General procedures.

Comparison of the toxicities of cyclin-dependent kinase inhibitors (Olomoucin and Roskovitin) and the toxicity of risk elements

Because of poor solubility of the agents, the biotest was performed in salt water at a total salt concentration of $0.9 \%$. Solubility of Roskovitin in water was very poor. Consequently this agent was dissolved in a mixture of dimethyl sulphoxide (DMSO, $10 \mathrm{~g} \cdot \mathrm{l}^{-1}$ ) and Tween 80 (TW, $5 \mathrm{~g} \cdot 1^{-1}$ ). The toxicity of the solvents at the above concentrations was tested.

Statistical methods

Groups of 50 specimens were used in tests of each of the concentrations of the agents studied. The only indicator monitored was the lethality of experimental specimens. All values that failed to meet the requirements of Dean-Dixon test (Q test) at the significance level of $\alpha=0.05$ were excluded (compare Dvořák 1999).

The calculated and test values were plotted in 3D diagrams that expressed the dependence of Artemia salina death rate on the concentration of the tested agents and on time. 
Differences between different concentrations, types of toxic agents and their combinations were tested using the method described by Wayland and Hayes (1991). To identify significant relationships between different sets of data in a specific experiment or between different experiments, test of independence in contingency tables was used (Anděl 1985).

\section{Results}

Monitoring of co-exposures of low volume activity of ${ }^{89} \mathrm{Sr}$ and low cadmium, chromium and Delor 103 concentrations

None of the agents (Delor $103\left(4.5 \mathrm{ng} \cdot \mathrm{l}^{-1}\right.$, lethality $\left.8 \%\right)$, strontium $89\left(30 \mathrm{kBq} \cdot \mathrm{l}^{-1}\right.$, lethality $10 \%)$, cadmium chloride $\left(0.02 \mathrm{~g} \cdot \mathrm{l}^{-1}\right.$, lethality $\left.12 \%\right)$ caused any significant toxic effect except for potassium dichromate $\left(0.05 \mathrm{~g} \cdot \mathrm{l}^{-1}\right)$ whose lethality was $27 \%$. However, the co-exposure of all the agents lead to the high lethality of $81 \%$ (Fig. 1).

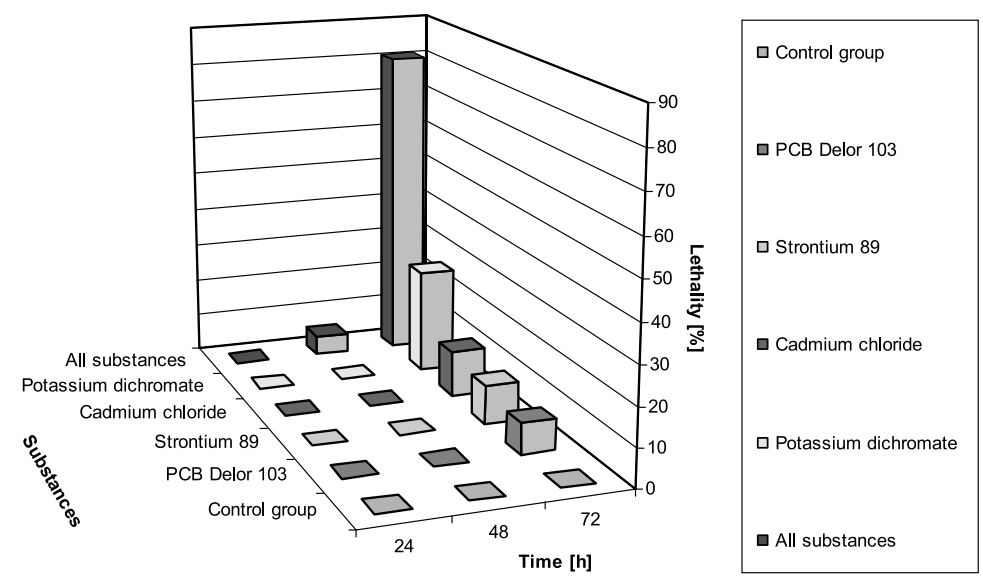

Fig. 1. Lethality of A. franciscana during co-exposure of ${ }^{89}$ strontium $30 \mathrm{kBq} \cdot \mathrm{l}^{-1}$, PCB - Delor $1034.5 \mathrm{ng} \cdot \mathrm{l}^{-1}$, cadmium chloride $\left(\mathrm{CdCl}_{2} \cdot 2.5 \mathrm{H}_{2} \mathrm{O}\right) 0.02 \mathrm{~g} \cdot \mathrm{l}^{-1}$, and potassium dichromate $0.05 \mathrm{~g} \cdot \mathrm{l}^{-1}$.

Anti-oxidative and pro-oxidative effects of various concentrations of the ascorbic acid

The effects of co-exposure of hydrogen peroxide $0.4 \mathrm{~g} \cdot \mathrm{l}^{-1}$ and the ascorbic acid are shown in Fig. 2. Contrary to the effects of these agents used separately, the chart shows a significant $(\alpha=0.05)$ pro-oxidative effect of the ascorbic acid at the concentration of $0.3 \mathrm{~g} \cdot \mathrm{l}^{-1}$ used in combination with hydrogen peroxide at the concentration of $0.4 \mathrm{~g} \cdot \mathrm{l}^{-1}$. On the other hand, co-exposure of hydrogen peroxide and the ascorbic acid at concentrations $0.4 \mathrm{~g} \cdot \mathrm{l}^{-1}$ and $0.1 \mathrm{~g} \cdot 1^{-1}$ respectively, revealed the anti-oxidative action of the ascorbic acid by a decrease in lethality $(\alpha=0.05)$. The quenching effect of the ascorbic acid at $0.1 \mathrm{~g} \cdot \mathrm{l}^{-1}$ persisted throughout the experiment (24-120 h). It became most distinctive after a 96-h exposure when lethality had dropped by $34 \%$ compared to the effects of hydroxide peroxide alone.

Comparison of the toxicities of cyclin-dependent kinase inhibitors (Olomoucin and Roskovitin) and the toxicity of risk elements

Fig. 3 shows a comparison between Olomoucin and Roskovitin toxicities and the toxicities of risk elements, namely chromium, zinc and cadmium. All agents were used at the concentration of $0.1 \mathrm{~g} \cdot \mathrm{l}^{-1}$. The test lasted $120 \mathrm{~h}$ at $0.9 \%$ salinity. Olomoucin dissolved in dimethyl sulphoxide (DMSO) showed higher toxicity than Olomoucin dissolved in a mixture of DMSO and Tween (TW). But only the results for $96 \mathrm{~h}$ exposure proved to be significant. Chromium in the form of potassium dichromate proved to be the most toxic risk element. Its toxicity was significantly higher than that of Olomoucin or Roscovitin (both dissolved in a mixture of DMSO+TW) in 


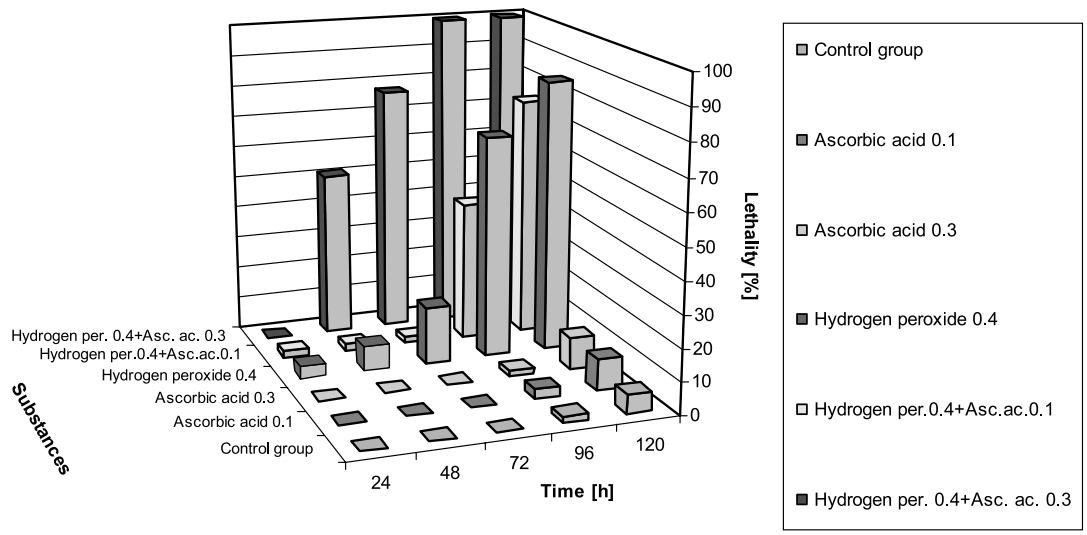

Fig. 2. Lethality of $A$. franciscana during exposure with ascorbic acid $0.1 \mathrm{~g} \cdot \mathrm{l}^{-1}$, ascorbic acid $0.3 \mathrm{~g} \cdot \mathrm{l}^{-1}$, hydrogen peroxide $0.4 \mathrm{~g} \cdot \mathrm{l}^{-1}$, and co-exposure hydrogen peroxide $0.4 \mathrm{~g} \cdot \mathrm{l}^{-1}$ and ascorbic acid $0.1 \mathrm{~g} \cdot \mathrm{l}^{-1}$ or hydrogen peroxide $0.4 \mathrm{~g} \cdot \mathrm{l}^{-1}$ and ascorbic acid $0.3 \mathrm{~g} \cdot \mathrm{l}^{-1}$.

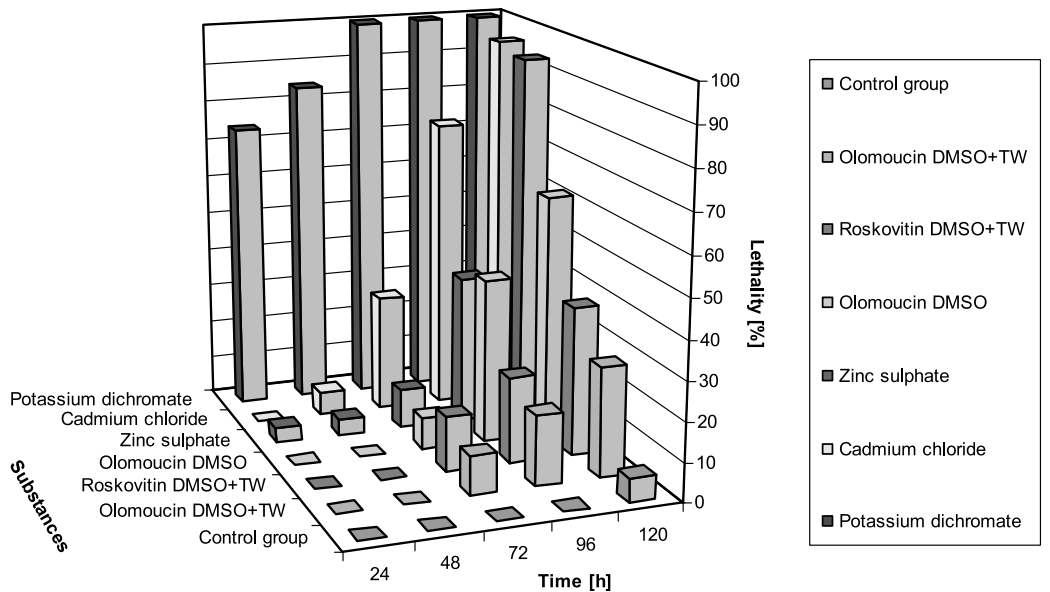

Fig. 3. Comparison between Olomoucin (OC) and Roskovitin (ROS) toxicities and the toxicities of solvents dimethylsulphoxide, Tween and the toxicities of risk elements Zinc sulphate heptahydrate $\left(\mathrm{ZnSO}_{4} \cdot 7 \mathrm{H}_{2} \mathrm{O}\right)$; cadmium chloride $\left(\mathrm{CdCl}_{2} \cdot 2.5 \mathrm{H}_{2} \mathrm{O}\right)$ and potassium dichromate $\left(\mathrm{K}_{2} \mathrm{Cr}_{2} \mathrm{O}_{7}\right)$ at $0.9 \%$ ambient salinity. All substances are at the concentration of $0.1 \mathrm{~g} \cdot 1^{-1}$.

all exposures. Cadmium had significantly higher toxicity than Olomoucin (at exposures higher than $72 \mathrm{~h}$ ) or Roskovitin (at exposures higher than $96 \mathrm{~h}$ ). Zinc had significantly higher toxicity than Olomoucin dissolved in DMSO+TW (at exposures higher than $96 \mathrm{~h}$ ) or Roskovitin (at exposures higher than $120 \mathrm{~h}$ ).

\section{Discussion}

The genus Artemia is a member of the order Anostraca representing a group of crustaceans of the class Branchipoda. The Artemia populations have been found in about 500 salt lakes and salt works in the temperate, subtropical and tropical climate zones. Artemia prefer the salinity of $47 \mathrm{~g} \cdot \mathrm{l}^{-1}$ but they can survive at salinity of up to $250 \mathrm{~g} \cdot \mathrm{l}^{-1}$ as well (Ruppert et al. 2003). 
Test validation criteria depend on the lethality of control groups, which should not exceed $10 \%$ in a $96 \mathrm{~h}$ test and $20 \%$ at exposures exceeding $120 \mathrm{~h}$ (Dvořák et al. 2009). Since diapausing eggs of A. franciscana are commercially canned for aquaristic purposes, we can very easily and cheaply obtain more or less homogenous populations consisting of millions of specimens (Dvořák et al. 2009).

As ${ }^{89} \mathrm{Sr}$ is a beta radiation emitter, we cannot evaluate the real dose received by specimens during an experiment. Consequently, the effects of strontium in this study are given in volume activity units of $\mathrm{kBq} \cdot \mathrm{l}^{-1}$.

Hexavalent chromium damages DNA, decreases its synthesis and enhances oxidative processes in cells. Similar effects are produced by ionizing radiation.

The effects of strontium 89 or Delor 103 were not significantly different from those of the control group. On the other hand, co-exposure of those agents together with potassium dichromate led to a significantly different value than that of the control group. We assume that the effects of both agents, i.e. Delor 103 and strontium 89 were due to the damage of membrane integrity resulting in higher penetration of both potassium dichromate and cadmium chloride. Cadmium, on the other hand, induces production of metallothioneins (Kovářová et al. 2009), i.e. substances that exhibit radioprotective effects (Beňová et al. 2006). A biotest using $A$. franciscana to monitor the cumulative effects of $\mathrm{Cd}, \mathrm{Cu}, \mathrm{Pb}$ and $\mathrm{Zn}$ in sediments has been published (Fichet et al. 1998).

Our experiments have demonstrated the possibilities of use of the presented biotest as a sensor for the co-exposure of a number of agents at various concentrations, as well as of ionizing irradiation.

The search for scavengers of reactive forms of oxygen (free radicals) is one of the priority fields of modern pharmacology. They include a number of agents and their effects depend largely on their concentrations. In our experiment, co-exposure of hydrogen peroxide and ascorbic acid at concentrations of $0.4 \mathrm{~g} \cdot \mathrm{l}^{-1}$ and $0.1 \mathrm{~g} \cdot \mathrm{l}^{-1}$, respectively, reduced the toxicity to a greater extent than hydrogen peroxide at $0.4 \mathrm{~g} \cdot \mathrm{l}^{-1}$ per se. This fact confirms the generally well-known anti-oxidative efficiency of the ascorbate (Young et al. 1992). Lethality, however, was lower than that of the control group. Consequently, one can assume that ascorbic acid is able to partially eliminate the effects of hydrogen peroxide, at least in this experimental design. The increase of concentration of the ascorbic acid had led to higher elimination of the effects of hydrogen peroxide. On the other hand, lethality was increased already at the concentration of $0.3 \mathrm{~g} \cdot \mathrm{l}^{-1}$. Results of our test are in agreement with the clinically well-known studies showing that ascorbic acid exposures higher than $1000 \mathrm{mg}$ per day have pro-oxidative effects whereas lower concentrations act as scavengers of the reactive forms of oxygen. A. franciscana therefore proved its utilization as a convenient biosensor for pharmacological studies of relations between exposure and its biological effects. The experimental design described in these experiments has recently been used in studies with some other prospective agents including plant extracts but the results have not been published yet.

One of the most promising groups of antitumour chemotherapeutics is the cyclindependent kinase inhibitors (CDKI) (Benson et al. 2005). The first synthetic purine inhibitor of CDKI was Olomoucin (Hajduch et al. 1999; Kryštof et al. 2002). The development of new pharmaceuticals has inevitably involved studies of their toxicity. This fact offers exceptional opportunity for the second generation biotest that may replace some experiments on vertebrates.

Due to the low solubility of CDKI in salt water, we decreased the concentrations of salt water to $0.9 \%$ in experiments with those agents. This caused a reduction in the ionic strength of the solution and an increase in their solubility. However, in such experiments it was impossible to extend the tests to ten days by the addition of glucose (Dvořák et al. 2005). Dimethyl sulphoxide (DMSO) proved as a very useful solvent in these experiments. It has 
excellent dissolving capacity for the agents tested and low toxicity for A. franciscana. The concentration of DMSO used for the dissolution of purine CDKI was $15 \mathrm{~g} \cdot \mathrm{l}^{-1}$. This approach is not suitable in all applications (e.g. in case of Roskovitin). Other co-solvents may include nonionic tensides, such as Polysorbat 80 (Tween 80), and poloxamers (Pluronic F-68). To solve hardly soluble agents, combinations of DMSO $\left(10 \mathrm{~g} \cdot \mathrm{l}^{-1}\right)$ and Tween 80 or Pluronik at concentrations of $5 \mathrm{~g} \cdot \mathrm{l}^{-1}$ are mostly used (Sklenár et al. 2006). When DMSO was used in combination with another co-solvent, only $10 \mathrm{~g} \cdot \mathrm{l}^{-1}$ concentration was applied.

The toxicity of Olomoucin dissolved in DMSO + Tween was significantly lower than that of the combination Olomoucin + DMSO without Tween. This effect was probably caused by the prolonged life span of $A$. franciscana in salt water containing Tween (Fig. 3).

Our biotests with $A$. franciscana have demonstrated considerable possibilities for the use of these organisms as biosensors. This experimental system was successfully proved in experiments with more than 10,000 specimens. It is obvious that the conventional tests on vertebrates cannot compete with these tests in terms of quantities. These tests offer new possibilities for toxicity testing of various environmental agents and their combinations at low concentrations. The biotests can be used in pharmaco-toxicological studies of newly synthesized CDKI as well. Of course, such alternative biotests cannot fully replace the conventional tests on laboratory vertebrates, but they have the potential to markedly reduce the number and extent of such experiments.

\section{Alternativní biotesty II. generace na korýši rodu Artemia}

V naší práci jsme sledovali možnosti využití slanovodního korýše Artemia franciscana a popsali možnosti uspořádání a použití alternativního biotestu II. generace. Vedle klasického využití v ekotoxikologii existuje i možnost modelovat farmakologické experimenty nebo sledovat účinky ionizujícího záření v interakci s dalšími chemickými látkami.

Významnou oblastí je hledání biosenzorů vhodných pro farmakologii a farmakotoxikologii. Je popsán experiment dokladující antioxidativní a prooxidativní účinky kyseliny askorbové v závislosti na její koncentraci. Příklad farmokotoxikologického screeningu při hledání nových inhibitorů cyklindependentních kináz rovněž dokládá, že Artemia franciscana představuje $\mathrm{v}$ uvedených prŕíkladech vhodný biosenzor nahrazující testy na vyšších obratlovcích.

\section{Acknowledgements}

This research was carried out in the frameworks of the Research Plan of the Ministry of Education, Youth and Physical Training of the Czech Republic MSMT6215712402 and VEGA 1/0423/08 of the Slovak Republic.

\section{References}

Anděl J 1985: Mathematical Statistics. SNTL, Alfa, Praha, 346 p.

Benson C, Kaye S, Workman P, Garrett M, Walton M, de Bono J 2005: Clinical anti-cancer drug development: targeting the cyclin-dependent kinases. Br J Cancer 92: 7-12

Beňová K, Dvořák P, Falis M, Daňová D 2006: Elimination of negative effects of cadmium in Artemia franciscana by exposure to ionizing radiation. Folia Vet Suppl 3 50: 21-22

Beňová K, Dvořák P, Falis M, Sklenář Z 2007: Interaction of low doses of ionizing radiation, potassium dichromate and cadmium chloride in Artemia franciscana biotest. Acta Vet Brno 76: 35-40

Councill of Europe 1976: European convention for the protection of animals kept for farming purposes. European Treaty Series Nr. 87, Strasbourg, European Council 1976.

Dvořák P 1995: Modified test with A. salina for the monitoring of interactions between exogenous substances. Toxicity and Biodegradability of Matters Important in Water Management. Milenovice, Research Institute of Fish Culture and Hydrobiology Vodnany and Aquachemie Ostrava, pp. 25-29

Dvořák P 1999: Monitoring of low doses expositions by ionizing radiation and harmful substances using bio-test with Artemia salina. Thesis, FVHE Brno, pp. 86-90

Dvořák P, Beňová K 2002: The investigation of interactions of low doses of ionizing radiation and risk factors by means of Artemia salina biotest. Folia Vet 46: 195-197

Dvořák P, Šcman E, Beňová K 2005: The development of a ten-day biotest using Artemia salina nauplii. Biologia, Bratislava 60: 593-597 
Dvořák P, Žd’árský M, Beňová K 2009: Possibilities of alternative generation II biotests at Artemia. Interdisc toxicol 2: $45-47$

Fichet D, Radenac G, Miramand P 1998: Experimental studies of impacts of harbour sediments resuspension to marine invertebrates larvae: Bioavailability of $\mathrm{Cd}, \mathrm{Cu}, \mathrm{Pb}$ and $\mathrm{Zn}$ and toxicity. Mar Pollut Bull 36: 509-518

Hajduch M, Havlíček L, Veselý J, Novotný R, Mihál V, Strnad M 1999: Synthetic cyclin dependent dinase inhibitors. New generation of potent anti-cancer drug. Adv Exp Med Biol 457: 341-353

Kovářová J, Kizek R, Adam V, Harustiaková D, Čelechovská O, Svobodová Z 2009: Effect of cadmium chloride on metallothionein lLevels in carp. Sensors 6: 4789-4803

Kryštof V, Lenobel R, Havlíček L, Kuzma M, Strnad M 2002: Synthesis and biological activity of Olomoucin II. Bioorg. Med Chem Lett 12: 3283-3286

Nováková J, Daňová D, Stríšková K, Hromada R, Míčková H, Rabíšková M 2007: Zinc and cadmium toxicity using a biotest with Artemia franciscana. Acta Vet Brno 76: 635-642

Pazourek J 1992: Biological Systems Simulation. Grada, Praha. 288 p.

Ruppert EE, Fox R S, Barnes RD 2003: Invertebrate zoology. Itps Thompson Learning, 435 p.

Russell WMS, Burch RL 1992: The Principles of Humane Experimental Technique. Methuen, London, 238 p.

Sklenář Z, Dvořák P, Beňová K 2006: Possible use of Artemia salina biotests in studies of toxicological effects of cyclin-dependent kinase inhibitors. Klin Farmakol Farm 20: 62-65

Wayland J, Hayes Jr. 1991: Dosage and Other Factors Influencing Toxicity. In Handbook of Pesticide Toxicology. Volume 1. General Principles. Academic Press: Nashville, USA, pp. 39-97

Young I S, Torney J J, Trimble E R 1992: The effect of ascorbate supplementation on oxidative stress in the streptozocin diabetic rat. Free Radic Biol Med 13: 41-46 